\title{
Identifikasi Sektor Industri Pengolahan Unggulan Provinsi Jawa Timur (Analisis Input Output)
}

\author{
The Identification of the Leading Processing Industry Sector in East \\ Java Province (Input-Output Analysis)
}

\section{Totok Junari ${ }^{1}$, Ernan Rustiadi ${ }^{1}$ and Sri Mulatsih ${ }^{1}$}

Diterima: 8 Februari 2018

Diterima: 17 Agustus 2018

\begin{abstract}
Abstrak: Pemerintah Provinsi Jawa Timur memprioritaskan pengembangan industri yang mendukung pertumbuhan ekonomi agar menjadikannya pusat industri pengolahan sumber daya alam dan pertanian. Penelitian ini mengidentifikasi sektor unggulan industri pengolahan untuk dikembangkan di Provinsi Jawa Timur. Data penelitian ini menggunakan Tabel Input Output Provinsi Jawa Timur Tahun 2015. Metode yang digunakan menggunakan indikator analisis keterkaitan (Indek daya penyebaran dan Indek Derajat Kepekaan) dan kontribusi sektor terhadap output dan nilai tambah bruto. Hasil penelitian menunjukkan sektor industri makanan dan industri pengolahan tembakau adalah sektor industri unggulan Jawa Timur. Keduanya disamping memiliki IDK dan IDP > 1, dan total keduanya berkontribusi $50.22 \%$ membentuk output dan $51.9 \%$ nilai tambah bruto Jawa Timur. Sektor industri makanan dan pengolahan tembakau mempunyai keterkaitan ke belakang yang tinggi dengan sektor pertanian melalui pemanfaatan produk pertanian sebagai bahan baku industri. Total transaksi output sektor pertanian perikanan dan kelautan yang digunakan sektor industri pengolahan adalah Rp 180.01 Triliun, $72.79 \%$ diantaranya digunakan sektor industri makanan. Sektor industri pengolahan tembakau di Jawa Timur tidak lepas dari banyaknya aktifitas industrinya dan penyerapan tenaga kerja yang tinggi, serta ketersediaan bahan baku di Jawa Timur.
\end{abstract}

Kata kunci: keterkaitan, pertanian, sektor industri unggulan

Abstract: The government of East Java Province prioritizes the development of industry which supports economic growth to make it the center of processing for natural resource and agriculture industries. This research aims to identify the leading sector in the processing industry to be developed in East Java Province. The data of this research used Input-Output Table of East Java Province Year 2015. The used method was the analysis of relevance with Dispersion Index (IDP) and Sensitivity of Dispersion Index (IDK) and contribution of the processing industrial sectors in forming output and Gross Value Added. The results shows that food and tobacco processing industries are the leading industrial sectors in East Java. Both have IDK and IDP >1, and both contribute $50.22 \%$ to total output and $51.9 \%$ East Java's added value. The food industries have a high backward linkage with the agricultural sector through the utilization of agricultural products as industrial raw materials. The total transactions of fishery and marine fishery sector used by the manufacturing sector are Rp 180.01 trillion, $72.79 \%$ of which is used by the food industry sector. Tobacco processing industry sector in East Java is not separated from the many industrial activities and high employment, as well as the availability of raw materials in East Java.

Keywords: relevance, agriculture, leading industrial sector.

\footnotetext{
${ }^{1}$ Program Studi Ilmu Perencanaan Pembangunan Wilayah dan Perdesaan, Institut Pertanian Bogor
} 


\section{PENDAHULUAN}

Pengalaman di hampir semua negara menunjukkan bahwa industrialisasi sangat perlu dalam mendukung pembangunan ekonomi wilayah, karena proses industrialisasi menjamin tercapainya pertumbuhan ekonomi. Pemerintah mempermudah masuknya investasi di sektor industri pengolahan untuk mendorong pertumbuhan ekonomi dan sekaligus meningkatkan penyerapan tenaga kerja. Sektor industri pengolahan didorong untuk mengolah bahan mentah, agar dapat meningkatkan nilai tambah serta menciptakan kesempatan kerja baru. Sektor industri diharapkan menjadi mesin penggerak utama perekonomian nasional, tulang punggung ketahanan ekonomi yang berbasis sumberdaya nasional dan memiliki struktur keterkaitan dan kedalaman yang kuat, serta memiliki daya saing yang tangguh di pasar internasional. Bagi pemerintah daerah arah pengembangan sektor industri pengolahan harus memperhatikan karakteristik daerah masing-masing, suatu daerah tidak harus membangun keseluruhan sektor industri, namun hendaknya mengidentifikasi potensinya (Nazara, 2008).

Sektor industri pengolahan memberikan sumbangan terbesar dalam pembentukan PDRB Jawa Timur. Kontribusi sektor industri pengolahan mencapai $29.29 \%$ dari total PDRB Jawa Timur dan berkontribusi $20 \%$ terhadap pembentukan output sektor industri pengolahan nasional. Namun tenaga kerja yang bekerja di bidang sektor industri masih relatif kecil dibanding sektor pertanian. Hal ini menunjukkan tenaga kerja pada sektor pertanian memperoleh pendapatan yang relatif rendah dan tergolong dalam kelompok masyarakat miskin. Untuk itu perlu secara bertahap meningkatkan penyerapan tenaga kerja pada sektor industri pengolahan sehingga menjadi relatif lebih proporsional sesuai dengan kontribusinya terhadap PDRB.

Pemerintah meminta Provinsi Jawa Timur untuk fokus kepada tiga sektor utama yang menyangga perekonomian daerahnya, yaitu sektor industri pengolahan, perdagangan dan jasa, dan sektor pertanian. Sektor industri diarahkan untuk menjalankan hilirisasi industri untuk menghasilkan produk bernilai tambah tinggi, memperkuat struktur industri, menyediakan lapangan kerja serta peluang usaha (KADIN 2016). Salah satu tantangan yang dihadapi sektor industri pengolahan di Jawa Timur adalah masih lemahnya keterkaitan antar industri (industri hulu dan hilir maupun antara industri besar dengan industri kecil dan menengah) (BPS, 2016). Pemerintah Provinsi Jawa Timur memprioritaskan pengembangan industri yang membangun mata rantai produksi sektor pertanian yang menjadi kontributor utama pertumbuhan ekonomi Jatim. Pengembangan industri diharapkan akan meningkatkan nilai ekonomis produksi pertanian, Jawa Timur diharapkan akan menjadi pusat industri pengolahan sumber daya alam dan pertanian. Mengingat keterbatasan sumberdaya yang tersedia, maka perlu adanya skala prioritas pembangunan, dalam konteks pembangunan sektoral perlu adanya sektor unggulan / strategis yang didorong untuk menggerakkan ekonomi. Dari latar belakang tersebut, penelitian ini bertujuan mengidentifikasi sektor industri pengolahan unggulan di Provinsi Jawa Timur.

Sektor unggulan adalah sektor yang memiliki peranan yang relatif besar dibanding sektor-sektor lainnya dalam memacu tujuan pertumbuhan ekonomi. Dalam pengembangan sektor industri, maka sektor industri unggulan tersebut mampu memberikan sumbangan yang besar dalam perekonomian wilayah dan memiliki keterkaitan yang tinggi secara sektoral dan spasial. Perkembangan sektor tersebut akan memberikan dampak langsung dan tidak langsung yang tinggi bagi sektor lainnya (Rustiadi et al, 2011). Beberapa aspek yang bisa dijadikan pendekatan untuk mengidentifikasi sektor unggulan (Arief, 1993), meliputi:

1. Suatu sektor dianggap sebagai sektor kunci apabila mempunyai keterkaitan ke belakang dan kaitan ke depan yang relatif tinggi. 
2. Suatu sektor dianggap sebagai sektor kunci apabila menghasilkan output bruto yang relatif tinggi.

3. Suatu sektor dianggap sebagai sektor kunci apabila mampu menciptakan lapangan kerja yang relatif tinggi.

Berdasarkan aspek-aspek yang menjadi pertimbangan sektor unggulan/ strategis, maka dalam pengkajian ini kriteria penentuan sektor industri unggulan/ strategis meliputi:

1. Memiliki keterkaitan antar sektor yang tinggi dengan ditunjukkan dari indek daya penyebaran (DP) dan indek derajat kepekaan (DK) $>1$.

2. Memiliki sumbangan pada pembentukan output, nilai tambah bruto dan penyerapan tenaga kerja yang tinggi.

\section{METODE PENELITIAN}

\section{Jenis dan Sumber Data}

Data yang digunakan dalam analisis ini adalah data sekunder berupa Tabel Input Output Provinsi Jawa Timur Tahun 2015 yang bersumber dari BPS Jawa Timur. Tabel input output yang digunakan adalah data transaksi total atas dasar harga produsen. Di dalam data tersebut terdapat 110 sektor ekonomi, untuk sektor industri pengolahan sendiri terdiri dari 40 sektor dan untuk keperluan analisis ini sektor industri pengolahan diagregasikan menjadi 24 sektor industri pengolahan sebagaimana klasifikasi dalam dalam KBLI 2015.

\section{Metode Analisis}

Metode yang digunakan dalam menentukan sektor industri unggulan berdasarkan kriteriakriteria meliputi:

\section{Analisis Keterkaitan}

Analisis penentuan sektor unggulan utamanya diidentifikasi melalui keterkaitan ke depan (forward linkage) dan keterkaitan ke belakang (backward linkage) dengan menggunakan indek daya penyebaran dan indeks daya kepekaan. Hal ini mengingat bahwa penetapan sektor unggulan harus dipandang secara komprehensif, dan tidak semata-mata hanya ditentukan berdasarkan besar nilai pengganda ekonomi saja, namun juga harus memperhatikan keberlanjutan bahan baku, besarnya investasi, peluang pasar dan kondisi sosial ekonomi masyarakat juga menjadi faktor penting yang harus dipertimbangkan oleh pembuat kebijakan (Sinay, 2015).

a. Indek Daya Penyebaran (backward power of dispersion)

Untuk memperoleh Indek daya penyebaran, diidentifikasi dahulu kaitan ke belakang langsung dan tidak langsung (direct indirect backward linkage) (BLj). Nilai ini menunjukkan pengaruh tidak langsung dari kenaikan permintaan akhir suatu unit sektor tertentu (j) yang dapat meningkatkan total output seluruh sektor perekonomian. Parameter ini menunjukkan kekuatan suatu sektor dalam mendorong peningkatan seluruh sektor perekonomian, secara matematis diformulasikan sebagai berikut:

$$
B L_{j}=\sum_{i} b_{i j}
$$

Dimana bij adalah elemen-elemen matriks (I-A)-1 yang merupakan inverse matriks Leontief. Dari nilai dibl, selanjutnya dapat dihitung daya sebar ke belakang atau indeks daya penyebaran (backward power of dispersion) $(\beta \mathrm{j})$ dengan formula:

$$
\beta \mathrm{j}=\frac{\Sigma_{i} b_{j}}{\frac{1}{n} \Sigma_{i} \Sigma_{i} b_{j}}=\frac{n \Sigma_{j} b_{j}}{\sum_{i} \Sigma_{i} b_{j}}
$$


Indek ini menunjukkan kekuatan relative permintaan akhir suatu sektor dalam mendorong pertumbuhan produksi total seluruh sektor perekonomian. Jika $\beta \mathrm{j}>1$, maka secara relatif permintaan akhir sektor $\mathrm{j}$ dalam merangsang pertumbuhan produksi lebih besar dari rata-rata.

b. Indek Daya Kepekaan (forward power of dispersion)

Untuk menganalisis indek daya kepekaan, perlu dihitung dulu nilai kaitan ke depan langsung dan tidak langsung (direct indirect forward linkage) (FLi). Nilai ini menunjukkan peran suatu sektor (i) untuk dapat memenuhi permintaan akhir dari seluruh sektor perekonomian.

$F L_{i}=\Sigma_{j} b_{i j}$

Bila permintaan akhir tiap sektor perekonomian meningkat satu unit (yang berarti peningkatan permintaan akhir seluruh sektor perekonomian adalah sebesar $\mathrm{n}$ unit), dengan demikian maka sektor i menyumbang pemenuhannya sebesar FLi. Selanjutnya dapat dihitung nilai kepekaan terhadap signal pasar permintaan akhir atau indeks daya kepekaan (forward power of dispersion) ( $\alpha j$ ) dengan formula:

$\propto_{j}=\frac{\Sigma_{j} b_{j}}{\frac{1}{n} \sum_{i} \Sigma_{j} b_{j}}$

Indek ini menunjukkan sumbangan relative suatu sektor dalam memenuhi permintaan akhir keseluruhan sektor perekonomian. Jika suatu sektor memiliki karakteristik dengan $\alpha \mathrm{j}>1$, maka sektor tersebut merupakan salah satu sektor yang unggulan, karena secara relative dapat memenuhi permintaan akhir diatas.

2. Kontribusi sektor industri pengolahan dalam pembentukan output, dan nilai tambah bruto.

Analisis ini mengidentifikasi sektor-sektor industri pengolahan mana yang berkontribusi besar dalam pembentukan output, dan nilai tambah bruto di Provinsi Jawa Timur.

\section{HASIL DAN PEMBAHASAN}

Sektor industri pengolahan berkontribusi besar dalam struktur perekonomian Provinsi Jawa Timur, hal ini dapat diidentifikasi dari kontribusinya dalam pembentukan output, dan nilai tambah bruto sebagaimana ditampilkan pada Tabel 1 . Total nilai output Provinsi Jawa Timur sebesar Rp 3,182.56 triliun, sektor industri pengolahan berkontribusi sebesar $40.39 \%$ atau sebanding dengan nilai $\mathrm{Rp} 1,285.29$ triliun. Sedangkan dalam pembentukan nilai tambah bruto Provinsi Jawa Timur dengan total nilai Rp 1,689.88 triliun, kontribusi sektor industri pengolahan sebesar $29.27 \%$ atau senilai Rp 494.69 triliun. Kondisi ini menunjukkan sektor industri pengolahan adalah sektor yang memegang peranan penting dalam menunjang perkembangan ekonomi wilayah di Provinsi Jawa Timur.

Sementara itu dari hasil analisis keterkaitan sektor industri pengolahan secara agregat, diketahui sektor industri pengolahan mempunyai keterkaitan ke belakang langsung dan tak langsung (DIBL) yang tinggi dengan nilai 2.1041 dengan peringkat ketiga terbesar setelah sektor Pengadaan Listrik dan Gas dan sektor Jasa Kesehatan dan Kegiatan Sosial. Di sisi lain industri pengolahan mempunyai nilai keterkaitan ke depan langsung dan tak langsung tertinggi dengan nilai 6.6951 yang merupakan nilai tertinggi.

Pada penelitian terdahulu, Santoso dan Suharjo (2014) menyatakan bahwa berdasarkan tabel IO Provinsi Jawa Timur Tahun 2010, sektor yang memiliki keterkaitan ke depan dan ke belakang relatif kuat terbanyak dengan sektor lainnya adalah sektor industri pengolahan. Sektor ini memiliki keterkaitan ke depan dengan seluruh sektor. Sedangkan untuk keterkaitan ke belakang, hanya sektor konstruksi yang tidak memiliki 
keterkaitan dengan sektor industri pengolahan yang berarti sektor industri pengolahan memberikan pengaruh cukup kuat untuk seluruh sektor ekonomi lainnya di Provinsi Jawa Timur. Dengan demikian sektor industri pengolahan merupakan sektor kunci dalam perekonomian Provinsi Jawa Timur jika dilihat dari keterkaitan ke depan dan keterkaitan ke belakangnya.

Tabel 1 Kontribusi Sektor Ekonomi Dalam Pembentukan Output, Permintaan Akhir Dan Nilai Tambah Bruto Provinsi Jawa Timur Tahun 2015 (Dalam Persen)

\begin{tabular}{rlrr}
\hline No & \multicolumn{1}{c}{ Sektor } & Output & NTB \\
\hline 1 & Pertanian, Kehutanan, dan Perikanan & 9.43 & 13.75 \\
2 & Pertambangan dan Penggalian & 2.57 & 3.79 \\
3 & Industri Pengolahan & 40.39 & 29.27 \\
4 & Pengadaan Listrik dan Gas & 2.09 & 0.34 \\
5 & Pengadaan Air, Pengel. Sampah, Limbah \& Daur Ulang & 0.08 & 0.09 \\
6 & Konstruksi & 10.44 & 9.50 \\
7 & Perdag. Besar \& Eceran, \& Reparasi Mobil \& Sepeda Motor & 11.64 & 17.64 \\
8 & Transportasi dan Pergudangan & 3.90 & 3.36 \\
9 & Penyediaan Akomodasi dan Makan Minum & 5.36 & 5.41 \\
10 & Informasi dan Komunikasi & 3.38 & 4.56 \\
11 & Jasa Keuangan & 1.99 & 2.75 \\
12 & Real Estate & 1.09 & 1.63 \\
13 & Jasa Perusahaan & 0.79 & 0.80 \\
14 & Admin. Pemerintahan, Pertahanan \& Jaminan Sosial Wajib & 2.41 & 2.31 \\
15 & Jasa Pendidikan & 2.21 & 2.72 \\
16 & Jasa Kesehatan dan Kegiatan Sosial & 1.15 & 0.71 \\
17 & Jasa lainnya & 1.08 & 1.35 \\
\hline & $\quad$ Nilai (triliun Rupiah) & & $1,689.88$ \\
\hline
\end{tabular}

Sumber: Tabel Input Output Provinsi Jawa Timur 2015 (diolah)

\section{Sektor Industri Unggulan}

Penentuan sektor industri pengolahan unggulan dilakukan dengan menganalisis aspek keterkaitan dengan sektor lain melalui IDP dan IDK, dan menganalisis kontribusinya dalam membentuk output, nilai tambah bruto dan penyerapan tenaga kerja.

\section{Indek Daya Penyebaran dan Indek Derajat Kepekaan}

Sektor-sektor unggulan di wilayah Provinsi Jawa Timur dapat juga dipetakan meliputi sektor-sektor yang memiliki indeks daya penyebaran (IDP) dan indeks derajat kepekaan $($ IDK) $>1$. Dikatakan sektor unggulan dikarenakan sektor yang memiliki IDP > 1, secara relatif permintaan akhir sektor tersebut merangsang pertumbuhan produksi lebih besar dari rata-rata, disisi lain sektor dengan IDK $>1$, maka sektor tersebut secara relatif dapat memenuhi permintaan akhir diatas kemampuan rata-rata dari sektor lainnya. Hasil perhitungan IDP dan IDK sektor-sektor industri pengolahan di Provinsi Jawa Timur pada Tabel 2 dan hasil scatterplotnya pada Gambar 1.

Dari perhitungan indek daya penyebaran hampir semua sektor memiliki indek $>1$, hal ini menunjukkan sektor-sektor industri di Jawa Timur memiliki keterkaitan ke belakang yang tinggi. Sektor dengan indek daya penyebaran tertinggi adalah industri karet, barang dari karet dan plasik dengan indek 1.5492. Hal ini dimungkinkan karena komponen industri karet dan plastic banyak menggunakan bahan-bahan yang banyak diproduksi oleh sektor lain. Di urutan kedua adalah industri barang galian bukan logam dengan indek 1.5225 , di urutan ketiga adalah industri logam dasar dengan indek 1.4590, disusul industri pengolahan batubara dan minyak bumi dengan indek 1.4164. Sementara untuk sektor yang indek daya penyebarannya $<1$ meliputi 2 sektor meliputi industri alat angkutan lainnya dan industri pakaian jadi. Sektor dengan indek daya penyebaran $>1$ menunjukkan secara relative permintaan akhir sektor tersebut merangsang pertumbuhan produksi sektor-sektor lainnya lebih besar dari rata-rata. 
Indek derajat kepekaan, diidentifikasi terdapat 9 sektor yang memiliki indek derajat kepekaan $>1$. Hal ini menunjukkan bahwa sektor-sektor tersebut memiliki kemampuan untuk menggerakkan produksi dari sektor-sektor hilir yang memanfaatkan input dari sektor-sektor ini. Beberapa sektor dengan indeks tertinggi adalah industri Bahan kimia dan barang dari bahan kimia dengan indek 4.8267, di urutan kedua adalah industri karet, barang dari karet dan plastic dengan nilai 4.7851, di urutan ketiga adalah industri pengolahan tembakau dengan indek 3.6029, keempat adalah industri makanan dengan indek 3.5853 dan kelima adalah industri logam dasar dengan indek 2.1879. Sektor-sektor dengan IDK $>1$ menunjukkan bahwa sektor-sektor tersebut secara relative dapat memenuhi permintaan akhir diatas rata-rata. Untuk menunjukkan posisi dari masingmasing sektor dalam klasifikasi kuadran sektoral, maka ditunjukkan dalam matrix plot pada gambar 1 .

Tabel 2 Indeks Daya Penyebaran Dan Indek Derajat Kepekaan Sektor-Sektor Industri Pengolahan Provinsi Jawa Timur Tahun 2015

\begin{tabular}{|c|c|c|}
\hline Sektor & IDP & IDK \\
\hline Industri Karet, barang dari karet dan plastic & $1.5492^{(1)}$ & $4.7851^{(2)}$ \\
\hline Industri Barang galian bukan logam & $1.5225^{(2)}$ & $1.0698^{(9)}$ \\
\hline Industri Logam Dasar & $1.4590^{(3)}$ & $2.1879^{(5)}$ \\
\hline Industri Batubara dan Pengilangan Migas & $1.4164^{(4)}$ & $0.8134^{(14)}$ \\
\hline Industri Farmasi, produk obat kimia dan obat tradisional & $1.3832^{(5)}$ & $1.1639^{(6)}$ \\
\hline Industri Peralatan Listrik & $1.3658^{(6)}$ & $0.6648^{(20)}$ \\
\hline Industri Barang Logam, Bukan Mesin dan Peralatannya & $1.3606^{(7)}$ & $1.0798^{(8)}$ \\
\hline Industri Bahan kimia dan barang dari bahan kimia & $1.3587^{(8)}$ & $4.8257^{(1)}$ \\
\hline Industri Komputer, Barang Elektronik dan Optik & $1.3540^{(9)}$ & $0.6255^{(23)}$ \\
\hline Industri Mesin dan Perlengkapan YTDL & $1.3127^{(10)}$ & $0.6613^{(21)}$ \\
\hline Industri Pengolahan Lainnya & $1.3070^{(11)}$ & $0.6753^{(19)}$ \\
\hline Industri Kulit, barang dari kulit dan alas kaki & $1.2577^{(12)}$ & $0.9889^{(10)}$ \\
\hline Industri Minuman & $1.2250^{(13)}$ & $0.7460^{(16)}$ \\
\hline Industri Furniture & $1.2123^{(14)}$ & $0.6613^{(22)}$ \\
\hline Industri Makanan & $1.1805^{(15)}$ & $3.5853^{(4)}$ \\
\hline Industri Kertas dan Barang dari Kertas & $1.1701^{(16)}$ & $0.9841^{(11)}$ \\
\hline Industri Percetakan dan Reproduksi Media Rekaman & $1.1688^{(17)}$ & $0.5829^{(24)}$ \\
\hline Jasa Reparasi dan pemasangan mesin dan peralatan & $1.1607^{(18)}$ & $0.6774^{(18)}$ \\
\hline $\begin{array}{l}\text { Industri Kayu, Brng. dari Kayu \& Gabus (Tidak Termasuk } \\
\text { Furnitur) \& Brng. Anyaman dr Bambu, Rotan \& Sejenisnya }\end{array}$ & $1.0401^{(19)}$ & $0.7991^{(15)}$ \\
\hline Industri Kendaraan bermotor Trailer dan semi Trailer & $1.0298^{(20)}$ & $1.1382^{(7)}$ \\
\hline Industri Tekstil & $1.0090^{(21)}$ & $0.8857^{(12)}$ \\
\hline Industri Pengolahan Tembakau & $1.0067^{(22)}$ & $3.6029^{(3)}$ \\
\hline Industri Alat Angkutan Lainnya & $0.9806^{(23)}$ & $0.8555^{(13)}$ \\
\hline Industri Pakaian Jadi & $0.9714^{(24)}$ & $0.6938^{(17)}$ \\
\hline
\end{tabular}

Sumber: Tabel I-O Provinsi Jawa Timur 2015 (diolah)

Terdapat 9 sektor industri yang memiliki IDP dan IDK $>1$, artinya sektor-sektor tersebut masuk dalam klasifikasi sektor unggulan/ strategis karena memiliki kemampuan keterkaitan ke belakang sekaligus ke depan yang diatas rata-rata. Sektor-sektor industri tersebut meliputi: sektor industri makanan (kode 36), industri pengolahan tembakau (48), industri bahan kimia dan barang dari bahan kimia (57), industri farmasi, produk obat dan obat tradisional (60), industri karet dan barang dari karet dan plastic (61), industri barang galian bukan logam (63), industri logam dasar (65), industri barang logam, bukan mesin, dan peralatannya (66), dan sektor industri kendaraan bermotor trailer dan semi trailer (70). 


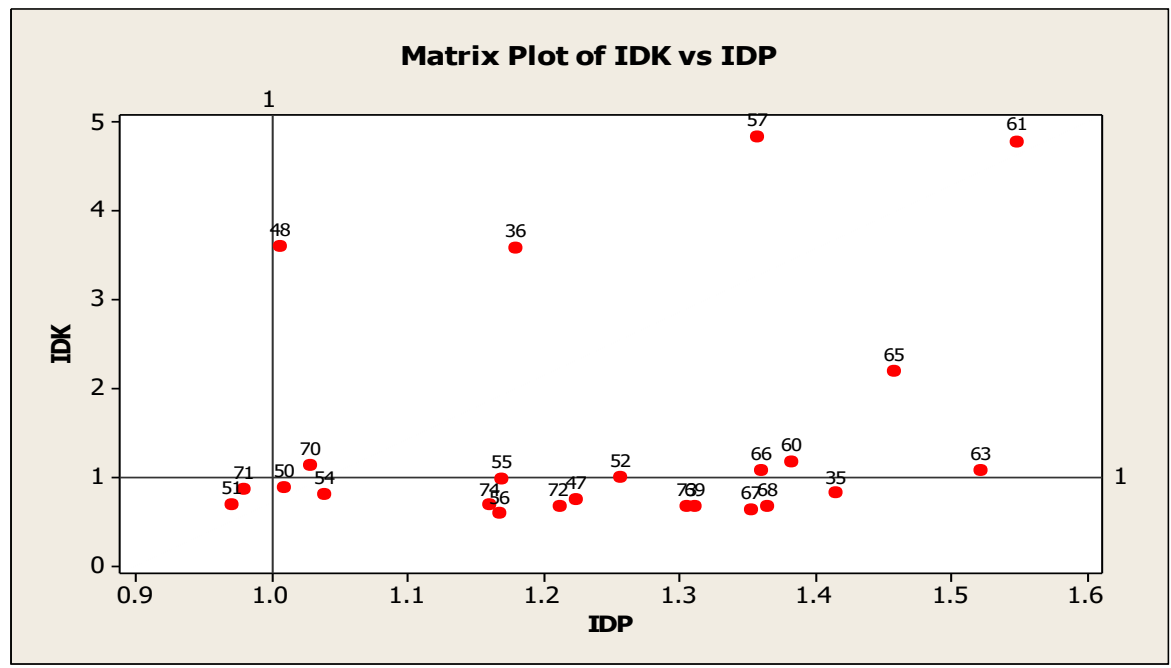

Gambar 1. Hasil Scatterplot Klasifikasi Indek Daya Penyebaran (IDP) Dan Indek Derajat Kepekaan Sektor Industri Pengolahan Provinsi Jawa Timur

Kontribusi dalam pembentukan output, dan nilai tambah bruto.

Salah satu kriteria dalam penentuan sektor industri pengolahan unggulan, adalah kontribusi sektor-sektor industri pengolahan tersebut dalam pembentukan output, nilai tambah bruto dan penyerapan tenaga kerja. Output merepresentasikan nilai produksi barang dan jasa yang dihasilkan oleh seluruh sektor-sektor ekonomi di suatu wilayah. Nilai Tambah Bruto adalah balas jasa yang diciptakan/ diberikan kepada faktor-faktor produksi yang berperan dalam proses produksi. Besarnya nilai tambah di tiap-tiap sektor tentunya ditentukan oleh besarnya output (nilai produksi) yang dihasilkan serta jumlah biaya yang dikeluarkan dalam proses produksi. Oleh karena itu suatu sektor yang memiliki output yang besar belum tentu memiliki nilai tambah yang besar, tergantung dari beaya produksi yang dikeluarkannya. Persentase kontribusi dari masing-masing sektor industri pengolahan terhadap pembentukan output, dan nilai tambah brutto ditunjukkan pada Tabel 3

Tabel 3 Kontribusi Sektor-Sektor Industri Dalam Pembentukan Output, Nilai Tambah Bruto dan Penyerapan Tenaga Kerja Provinsi Jawa Timur Tahun 2015 (Dalam Persen)

\begin{tabular}{lcc}
\hline \multicolumn{1}{c}{ Sektor Industri } & Output & NTB \\
\hline Industri makanan & $31.12^{(1)}$ & $27.66^{(1)}$ \\
Industri pengolahan tembakau & $19.10^{(2)}$ & $24.24^{(2)}$ \\
Industri bahan kimia \& barang dari bahan kimia & $8.94^{(3)}$ & $6.99^{(3)}$ \\
Industri karet, barang dari karet dan plastik & $6.27^{(4)}$ & $4.39^{(7)}$ \\
Industri barang galian bukan logam & $6.01^{(5)}$ & $4.22^{(8)}$ \\
Industri kayu, barang dari kayu dan gabus & $4.79^{(6)}$ & $5.83^{(4)}$ \\
Industri logam dasar & $4.55^{(7)}$ & $3.77^{(9)}$ \\
Industri barang logam, buka mesin \& peralatannya & $4.24^{(8)}$ & $4.41^{(6)}$ \\
Industri kertas dan barang dari kertas & $4.04^{(9)}$ & $4.56^{(5)}$ \\
Industri furniture & $2.59^{(10)}$ & $3.14^{(10)}$ \\
Industri farmasi, produk obat kimia \& obat tradisional & $2.52^{(11)}$ & $1.95^{(11)}$ \\
Industri minuman & $1.32^{(12)}$ & $1.08^{(14)}$ \\
Industri kulit, barang dan kulit dan alas kaki & $1.14^{(13)}$ & $1.34^{(12)}$ \\
Industri tekstil & $0.80^{(14)}$ & $1.09^{(13)}$ \\
Industri pengolahan lainnya & $0.67^{(15)}$ & $0.76^{(16)}$ \\
Industri alat angkutan lainnya & $0.53^{(16)}$ & $0.84^{(15)}$ \\
Industri pakaian jadi & $0.27^{(17)}$ & $0.43^{(17)}$ \\
Industri produk dari batu bara \& minyak bumi & $0.24^{(18)}$ & $0.19^{(21)}$ \\
Industri kendaraan bermotor, trailer \& semi trailer & $0.19^{(19)}$ & $0.30^{(18)}$ \\
\hline
\end{tabular}




\begin{tabular}{lcc}
\hline \multicolumn{1}{c}{ Sektor Industri } & Output & NTB \\
\hline Iindustri mesin \& perlengkapan ytdl & $0.18^{(20)}$ & $0.22^{(20)}$ \\
Industri percetakan \& reproduksi media rekaman & $0.17^{(21)}$ & $0.22^{(19)}$ \\
Industri computer, barang eletronik \& optik & $0.14^{(22)}$ & $0.14^{(23)}$ \\
Jasa reparasi \& pemasangan mesin & $0.13^{(23)}$ & $0.18^{(22)}$ \\
Industri peralatan listrik & $0.05^{(24)}$ & $0.05^{(24)}$ \\
\hline \multicolumn{1}{c}{ Nilai (dalam triliun rupiah) } & $\mathrm{Rp} \mathrm{1,285.29}$ & $\mathrm{Rp} \mathrm{494.69}$ \\
\hline
\end{tabular}

Dari output sektor industri pengolahan sebesar Rp 1,285.29 triliun, sektor yang berkontribusi besar dalam pembentukannya adalah sektor industri makanan yang mencapai $31.12 \%$ dan sektor industri pengolahan tembakau yang mencapai $19.1 \%$, disusul sektor industri bahan kimia dan barang dari bahan kimia yang menyumbang nilai sebesar 8.94\%. Sedangkan sektor Industri karet, barang dari karet dan plastik berkontribusi menyumbang $6.27 \%$ dan sektor industri barang galian bukan logam berkontribusi sebesar $6.01 \%$.

Sektor industri pengolahan berkontribusi membentuk Nilai Tambah Bruto sebesar $\mathrm{Rp} 494.69$ triliun, kontribusi terbesar pembentuknya berasal dari sektor industri makanan dengan nilai $27.66 \%$, disusul sektor industri pengolahan tembakau yang berkontribusi sebesar $26.24 \%$, sedangkan diurutan ketiga adalah sektor sektor industri bahan kimia dan barang dari bahan kimia sebesar 6.99\%.

Dari indikator kontribusi terhadap pembentukan output, dan nilai tambah bruto dapat diindikasikan bahwa sektor industri makanan dan sektor industri pengolahan tembakau berkontribusi besar. Dari perbandingan output dan nilai tambah bruto Industri makanan industri pengolahan tembakau, dapat ditarik kesimpulan bahwa industri pengolahan tembakau lebih efektif mendatangkan nilai tambah bruto. Industri makanan sekalipun menciptakan output yang lebih tinggi diindikasikan mempunyai beaya produksi yang besar, sementara untuk industri pengolahan tembakau memiliki beaya produksi yang lebih rendah atau lebih efisien sehingga menghasilkan nilai tambah bruto yang lebih tinggi meskipun dengan input yang sama.

Berdasarkan kriteria keterkaitan dengan sektor-sektor lain dan kriteria kontribusi terhadap pembentukan output, nilai tambah bruto dan penyerapan tenaga kerja diidentifikasi sektor industri pengolahan yang masuk dalam kategori paling unggul adalah industri makanan dan industri pengolahan tembakau. Kedua sektor tersebut memiliki tingat keterkaitan ke depan dan belakang yang paling tinggi dan memiliki kontribusi yang cuup besar dalam pembentukan output, nilai tambah bruto tertinggi.

\section{Pembahasan}

Dengan menggunakan table input output Jawa Timur tahun 2015, sektor industri pengolahan berkontribusi $40.39 \%$ terhadap pembentukan output dan $29.27 \%$ terhadap pembentukan nilai tambah bruto Provinsi Jawa Timur. Nilai tersebut merepresentasikan bahwa sektor industri pengolahan bisa dikatakan sebagai penggerak ekonomi Jawa Timur. Jika dibandingkan dengan kontribusi sektor pertanian perikanan dan kelautan, telah terjadi pergeseran struktur ekonomi di Provinsi Jawa Timur. Kondisi ini sejalan dengan teori pattern of development oleh Chenery yang memfokuskan perubahan struktural dalam tahapan proses perubahan ekonomi, industri dan struktur institusi dari perekonomian negara sedang berkembang, yang mengalami transformasi dari pertanian tradisional beralih ke sektor industri sebagai mesin utama pertumbuhan ekonominya. (Kuncoro, 2009).

Sementara itu Amir dan Nazara (2005), mengidentifikasi bahwa kondisi sektor industri di Jawa Timur Tahun 1994-2000, peran sektor industri lainnya dan sektor industri makanan, minuman dan tembakau sangat dominan dari sisi besaran outputnya, juga memiliki angka pengganda yang cukup tinggi. Dalam konteks klasifikasi sektor industri yang berbeda pada kajian ini, dimana kajian ini menggunakan klasifikasi berdasarkan 
KBLI 2015. Sektor industri pengolahan unggulan di Jawa Timur diidentifikasi adalah sektor industri makanan dan pengolahan tembakau.

Potensi kegiatan sektor industri makanan dan industri tembakau pengolahan tidak lepas dari jumlah perusahaan industri makanan paling banyak di Jawa Timur. Dari 6,672 unit industri pengolahan besar dan sedang di Jawa Timur, 1,843 diantaranya adalah kelompok industri makanan, dan industri pengolahan tembakau berjumlah 463 perusahaan. Lokasi perusahaan tersebut secara umum tersebar di seluruh wilayah Provinsi Jawa Timur dengan konsentrasi di wilayah Kota Surabaya, Sidoarjo, Pasuruan, dan Gresik.

Salah satu aspek yang didorong dalam pengembangan sektor industri pengolahan di Provinsi Jawa Timur adalah keterkaitan antar sektor-sektor industri pengolahan dalam memanfaatkan output sektor ekonomi lainnya sebagai bahan baku. Pemanfaatan sumberdaya bahan baku dari suatu wilayah akan memberikan manfaat efektifitas sumberdaya yang dimanfaatkan suatu sektor dalam melaksanakan proses produksi. Keterkaitan ini bisa ditunjukkan dari transaksi antar sektor dan dari matrik kebalikan leontief. Dalam kajian ini diidentifikasi keterkaitan antara sektor industri pengolahan dengan sektor pertanian perikanan dan kehutanan. Pola pembangunan di daerah-daerah negara maju yang diutamakan adalah pengembangan di sektor industri, hal ini disebabkan sektor industri dapat meningkatkan efisiensi penggunaan sumber-sumber yang tersedia untuk pembangunan daerah. Di daerah-daerah negara sedang berkembang pada umumnya merupakan daerah pertanian, karena itu cara pembangunan daerah yang terbaik adalah pengembangan industri dengan pemanfaatan produk pertanian (Suryani, 2007).

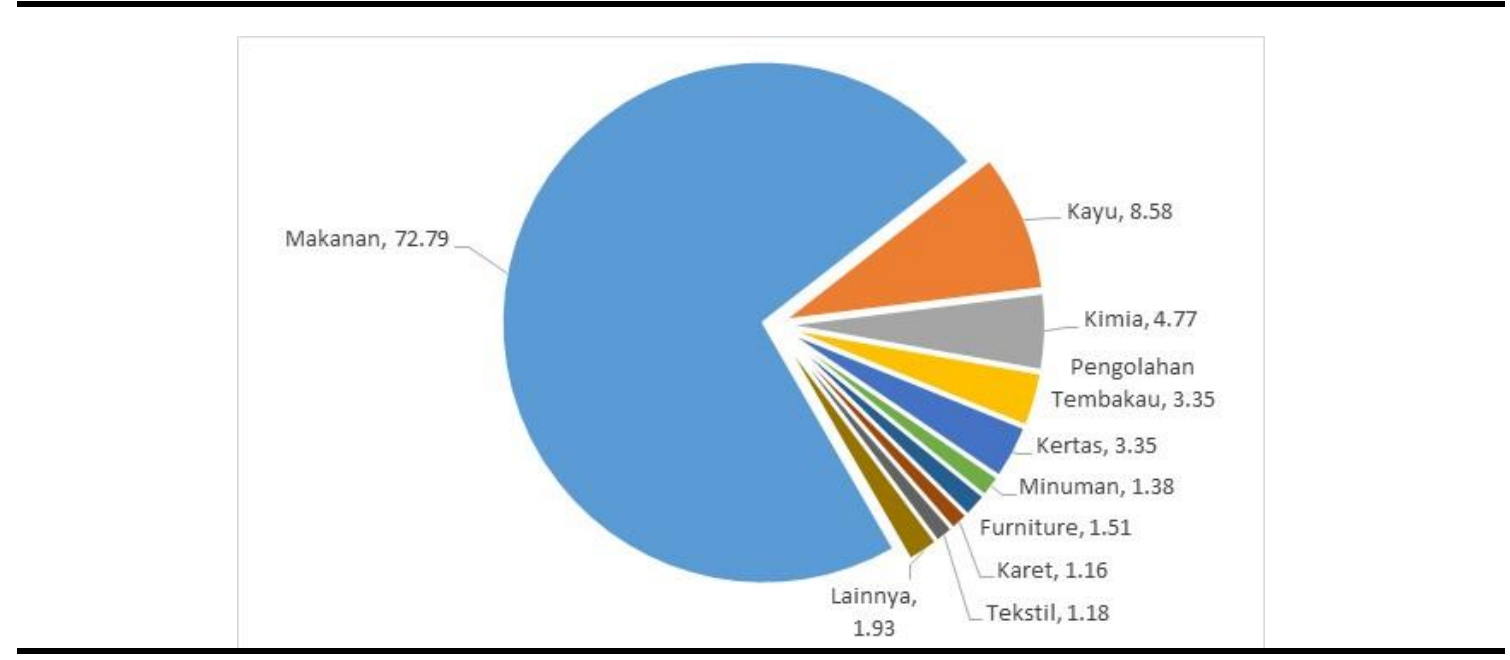

\section{Gambar 2 Proporsi Transaksi Keterkaitan Sektor Pertanian Perikanan Dan Kehutanan Oleh Sektor- Sektor Industri Pengolahan}

Proporsi keterkaitan transaksi antar output sektor pertanian yang digunakan dalam produksi sektor industri pengolahan digambarkan pada Gambar 2. Total transaksi sektor pertanian perikanan dan kehutanan yang digunakan sebagai input sektor industri pengolahan adalah sebesar Rp 180.01 triliun. Nilai ini adalah nilai transaksi antar sektor terbesar kedua setelah keterkaitan antara sektor industri dengan sektor industri itu sendiri. Dari nilai keterkaitan transaksi dari output sektor pertanian yang digunakan sebagai input produksi sektor-sektor industri pengolahan yang tertinggi adalah pemanfaatan sektor pertanian oleh sektor industri makanan dengan nilai $72.79 \%$ dari total transaksi, disusul pemanfaatan sektor pertanian oleh sektor industri kayu, barang dari kayu, gabus (tidak 
termasuk furniture) dan barang anyaman dari bambu, rotan dan sejenisnya sebesar $8.58 \%$. Di urutan ketiga adalah sektor bahan kimia dan barang dari bahan kimia dengan pemanfaatan sebesar $4.77 \%$.

Total transaksi sektor pertanian perikanan dan kehutanan oleh sektor industri makanan senilai $\mathrm{Rp} 131.03$ triliun atau sebanding dengan $72.79 \%$ dari total transaksi pertanian ke sektor industri pengolahan. Adapun komoditas sektor pertanian yang digunakan oleh sektor industri makanan meliputi dari komoditas padi senilai Rp 49.6 triliun, komoditas kelapa senilai Rp 13.8 triliun, komoditas tanaman pangan lainya senilai $\mathrm{Rp} 10.5$ triliun dan komoditas jagung senilai $\mathrm{Rp} 8.14$ triliun.

Sementara itu untuk sektor industri pengolahan tembakau di Jawa Timur perkembangannya tidak lepas dari potensi tembakau dan juga aktifitas industri pengolahan tembakau yang ada di Jawa Timur. Dalam produksi tembakau dunia, Indonesia menyumbang 191,110 ton atau sebanding dengan 3.01\% dari produksi dunia. Jawa Timur memproduksi 100,162 ton atau sebanding dengan $52.41 \%$ dari total produksi nasional disamping NTB, Jawa Tengah dan Jawa Barat (BPS, 2016).

Dari matrik kebalikan Leontief, diketahui keterkaitan sektor industri pengolahan dengan sektor pertanian perikanan dan kehutanan meliputi koefisien 0.2395 , artinya setiap peningkatan permintaann akhir sektor industri pengolahan akan meningkatkan output sektor pertanian sebesar 0.2395 kali. Nilai tersebut adalah koefisien terbesar output sektor pertanian yang digunakan sektor lain. Sedangkan keterkaitan sektor-sektor industri pengolahan yang memiliki keterkaitan dengan sektor pertanian diilustrasikan pada Gambar 3.

Sektor industri pengolahan yang mempunyai keterkaitan tertinggi dengan sektor pertanian adalah sektor industri makanan dengan nilai koefisien 0.4606 . Nilai ini berarti bahwa setiap peningkatan permintaan akhir sektor industri makanan akan meningkatkan output sektor pertanian sebesar 0.4606 kali. Hal ini dipahami bahwa sektor industri makanan banyak memanfaatkan output sektor pertanian. Sektor kedua yang mempunyai keterkaitan dengan sektor pertanian adalah sektor industri kayu, barang dari kayu, gabus (tidak termasuk furniture) dan barang anyaman dari bambu, rotan dan sejenisnya dengan nilai koefisien 0.3060 , di urutan ketiga adalah sektor industri minuman dengan nilai koefisien 0.2738

Disisi lain penggunaan bahan baku lokal dan impor pada sektor industri pengolahan di Jawa Timur diketahui bahwa pada beberapa sektor ketergantungan akan komponen impor masih besar. Sektor industri pengolahan lainnya adalah sektor dengan bahan baku impor tertinggi dengan komposisi $75.12 \%$ dari total bahan baku senilai Rp 3.69 trilyun, disusul Industri computer, barang elektronik dan optic adalah sektor dengan komponen impor yang tinggi hingga mencapai $70.88 \%$ dari total bahan baku senilai Rp 1.67 trilyun. Di peringkat ketiga adalah sektor industri kendaraan bermotor trailer dan semi trailer, yang menggunakan bahan baku impor sebesar $46.64 \%$ dari total bahan baku senilai Rp 6.84 trilyun. Dari sisi nilai, industri makanan justru merupakan industri dengan komponen impor tertinggi, sebesar Rp 18,39 trilyun atau sebesar $21.6 \%$ dari total bahan baku industri makanan, disusul industri bahan kimia dan barang dari bahan kimia dengan nilai bahan baku impornya yang mencapai Rp 8.73 trilyun, atau sebanding dengan $36.52 \%$. Sub sektor industri makanan yang menggunakan bahan baku impor tinggi adalah industri ransum hewan yang menggunakan bahan baku impor sebesar Rp 7.52 trilyun atau sebanding dengan $40.86 \%$ dari total nilai bahan baku impor industri makanan dan industri tepung terigu sebesar 6.39 triyun atau sebanding dengan $34.74 \%$ dari nilai impor bahan baku industri makanan. Penggunaan bahan baku impor yang tinggi menjadikan banyak sektor industri di Jawa Timur rentan dan tergantung akan nilai tukar rupiah terhadap mata uang asing. 


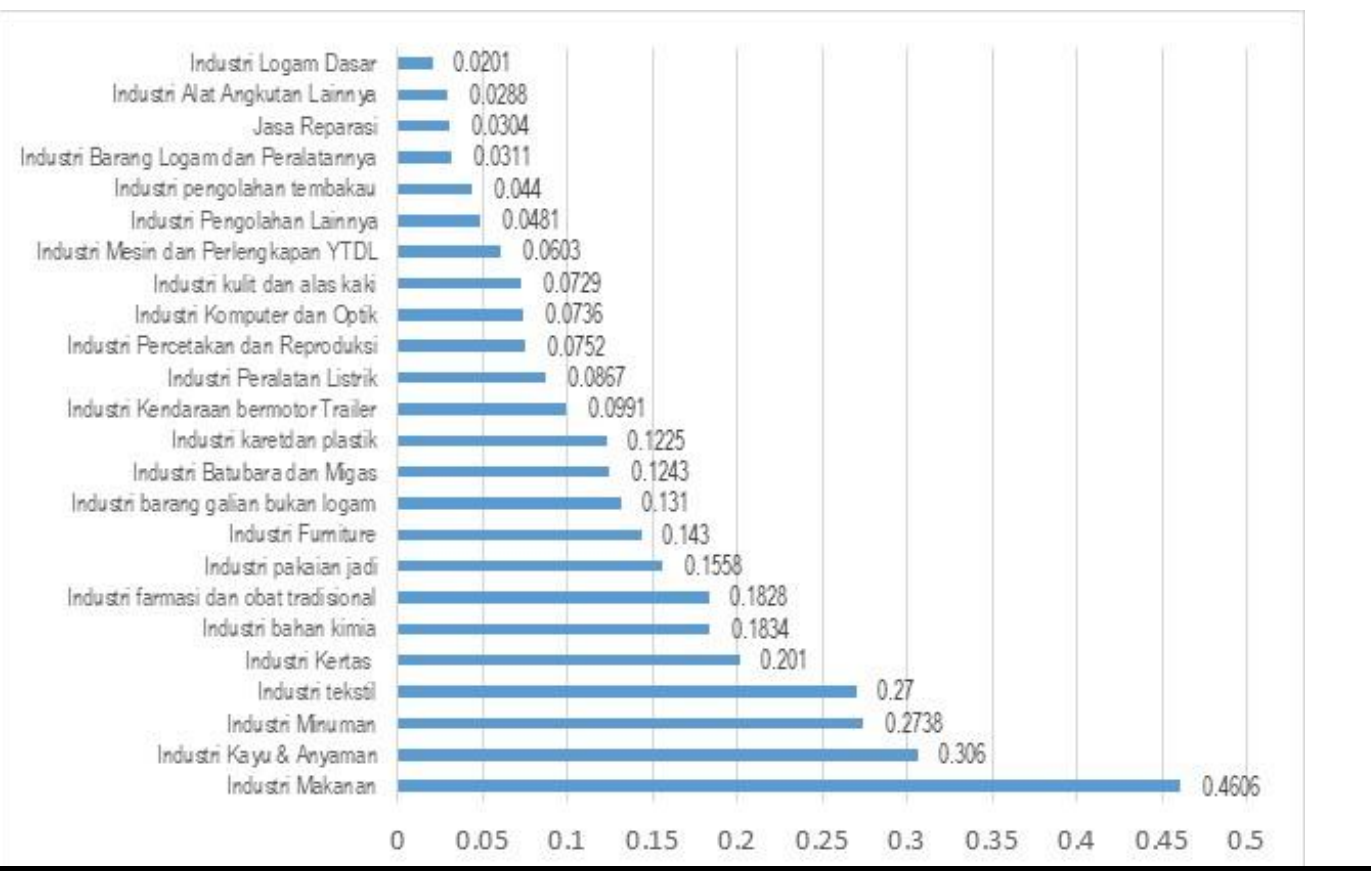

Gambar 3 Koefisien Keterkaitan Ke Belakang Langsung Dan Tidak Langsung Sektor-Sektor Industri Pengolahan Dengan Sektor Pertanian Perikanan Dan Kehutanan

Arianti (2008) dalam penelitiannya menyatakan bahwa sebenarnya kualitas bahan baku lokal, harga yang ditawarkan produsen bahan baku lokal dan pelayanan purna jual bahan baku lokal tidak terlalu mempengaruhi keputusan untuk mengimpor bahan baku dari luar negeri. Fakta ini menunjukkan bahwa bahan baku lokal cukup bersaing dengan bahan baku impor. Faktor yang dominan mengapa eksportir lebih dominan tergantung pada impor bahan baku dan luar negeri adalah kurangnya informasi tentang bahan baku lokal, disamping itu adalah faktor sudah menjadi tradisi sejak awal mengimpor bahan baku, serta aspek layanan purna jual produsen input lokal yang relative kurang baik dibanding dengan layanan pesaing dari negeri lain.

Tabel 4 Persentase Penggunaan Bahan Baku Lokal Dan Impor Sektor-Sektor Industri Pengolahan Jawa Timur Tahun 2015 (Dalam Trilyun Rupiah)

\begin{tabular}{lrrrrr}
\hline \multicolumn{1}{c}{ Sektor } & Lokal & $\begin{array}{c}\text { Proporsi } \\
\text { \% }\end{array}$ & Impor & $\begin{array}{c}\text { Proporsi } \\
\text { \% }\end{array}$ & Total \\
\hline Industri makanan & 66.56 & 78.34 & 18,40 & 21.66 & 84,96 \\
Industri minuman & 1.33 & 77.49 & 0.39 & 22.51 & 1,72 \\
Industri pengolahan tembakau & 29.10 & 98.30 & 0.50 & 1.70 & 29,60 \\
Industri tekstil & 6.47 & 81.92 & 1,43 & 18.08 & 7,90 \\
Industri pakaian jadi & 1.47 & 76.29 & 0.46 & 23.71 & 1,93 \\
Industri kulit \& alas kaki & 7.35 & 77.90 & 2,09 & 22.10 & 9,44 \\
Industri kayu dan gabus & 5.80 & 92.83 & 0.45 & 7.17 & 6,24 \\
Industri kertas \& barang dari kertas & 18.95 & 85.69 & 3,17 & 14.31 & 22,12 \\
Industri percetakan \& reproduksi media & 3.11 & 94.28 & 0.19 & 5.72 & 3,29 \\
Industri produk batu bara \& minyak bumi & 0.35 & 94.53 & 0.02 & 5.47 & 37 \\
Industri bahan kimia & 15.18 & 63.48 & 8,72 & 36.52 & 23,90 \\
Industri farmasi, \& obat tradisional & 1.39 & 66.76 & 0.69 & 33.24 & 2,09 \\
Industri karet \& plastik & 15.05 & 80.11 & 3,74 & 19.89 & 18,79 \\
Industri barang galian bukan logam & 4.77 & 81.55 & 1,09 & 18.45 & 5,84 \\
Industri logam dasar & 9.63 & 76.17 & 3,01 & 23.83 & 12,64 \\
Industri barang logam \& peralatannya & 4.84 & 63.05 & 2,84 & 36.95 & 7,68 \\
Industri computer, eletronik \& optik & 0.49 & 29.12 & 1,18 & 70.88 & 1,67 \\
Industri peralatan listrik & 4,24 & 73.16 & 1,56 & 26.84 & 5,80 \\
Industri mesin dan perlengkapan YTDL & 0.82 & 77.28 & 0.24 & 22.72 & 1,07 \\
\hline
\end{tabular}




\begin{tabular}{lrrrrr}
\hline \multicolumn{1}{c}{ Sektor } & Lokal & $\begin{array}{c}\text { Proporsi } \\
\text { \% }\end{array}$ & Impor & $\begin{array}{c}\text { Proporsi } \\
\text { \% }\end{array}$ & Total \\
\hline Industri kendaraan bermotor, dan trailer & 3.65 & 53.36 & 3,19 & 46.64 & 6,84 \\
Industri alat angkutan lainnya & 1,27 & 69.61 & 0.55 & 30.39 & 1,82 \\
Industri furniture & 3,86 & 87.44 & 0.56 & 12.56 & 4,42 \\
Industri pengolahan lainnya & 0.92 & 24.88 & 2,77 & 75.12 & 3,69 \\
Jasa reparasi \& pemasangan mesin & 0.12 & 96.68 & 0.004 & 3.32 & 0.12 \\
\hline \multicolumn{1}{c}{ Jumlah } & 206,69 & & 57,22 & & 263,91 \\
\hline
\end{tabular}

Sumber: BPS 2017

Sektor industri terus didorong untuk lebih banyak memanfaatkan bahan baku lokal, hal ini untuk menekan impor dan mencegah defisit neraca perdagangan yang lebih besar. Hal merupakan bagian dari kebijakan hilirisasi sumberdaya alam untuk meningkatkan produk yang bernilai tambah (Kemenperin, 2015). Untuk itu pengembangan sektor industri di Jawa Timur hendaknya terus didorong untuk mengembangkan keterkaitan antar sektor dan menangkap potensi bahan baku lokal di Jawa Timur maupun wilayah lain di Indonesia.

Pengembangan sektor industri makanan di Jawa Timur secara umum masih berpotensi untuk dikembangkan. Hal ini mengingat ekspor dari produk industri makanan di Jawa Timur masih relative kecil. Pada perdagangan Tahun 2015, total nilai ekspor Jawa Timur adalah 17,120,184,252 juta dollar, produk industri makanan yang diekspor senilai $834,121,891$ juta dollar, atau sebanding dengan $4.87 \%$. Kondisi ini dimungkinkan bahwa produk industri makanan lebih banyak dimanfaatkan untuk memenuhi kebutuhan pasar local yang besar.

Dalam pengembangannya terus diupayakan untuk mengembangkan industri yang memanfaatkan potensi bahan baku local khususnya produk hasil pertanian. Secara alamiah, perekonomian Jawa Timur merupakan perekonomian agraris dan sektor-sektor ini masih merupakan sektor-sektor yang menyerap tenaga kerja dalam jumlah yang relatif besar (Amir dan Singgih, 2005). Di samping pemanfaatan produk-produk pertanian dari wilayah Provinsi Jawa Timur, sektor industri pengolahan Jawa Timur juga hendaknya dapat menangkap potensi produk hasil pertanian maupun sumber bahan baku lainnya dari wilayah lain. Keterkaitan antar sektor ini diharapkan akan mengurangi ketergantungan akan bahan baku impor.

\section{KESIMPULAN}

Berdasarkan kemampuan keterkaitannya dengan sektor lain baik ke depan maupun ke belakang, serta kontribusinya yang cukup besar dalam pembentukan output, nilai tambah dan penyerapan tenaga kerja, teridentifikasi sektor industri makanan dan sektor industri pengolahan tembakau adalah sektor unggulan sektor industri pengolahan Jawa Timur. Kondisi ini didukung juga oleh faktor ketersediaan dan pemanfaaatan bahan baku local juga mendukung pengembangan kedua sector ini.

Disisi lain, pada sektor industri makanan masih mempunyai ketergantungan akan bahan baku impor, hal ini ditunjukkan dari komposisi $21.66 \%$ dari total bahan bakunya masih menggunakan bahan baku impor. Kondisi ini mendorong upaya pemanfaatan bahan baku lokal sebagai bagian substitusi bahan baku impor harus terus ditingkatkan. 


\section{DAFTAR PUSTAKA}

Amir H, dan Nazara, S. 2005. Analisis Perubahan Struktur Ekonomi (Economic Landscape) dan Kebijakan Strategi Pembangunan Jawa Timur Tahun 1994 dan 2000: Analisis Input Output, Jurnal Ekonomi dan pembangunan Indonesia, Vol V No 02, 2005 Januari, Hal 37-35

Amir H dan Riphat S, 2005. Analisis Sektor Unggulan Untuk Evaluasi Kebijakan Pembangunan Jawa Timur Menggunakan Tabel Input-Output 1994 dan 2000,Jurnal Keuangan dan Moneter - Departemen Keuangan RI, Edisi Desember 2005

Arianti, RK. 2008. Ketergatungan Beberapa Sektor Industri Terhadap Bahan Baku Impor. Buletin Ilmiah Litbang Perdagangan, Vol 2, No 1 Tahun 2008

Arief, S.1993. Metode Penelitian Ekonomi. LPFE-UI, Jakarta, 1993

Bappeda.jatimprov.go.id. 2017. Jatim Sumbang 50 Persen Pendapatan Cukai Rokok Nasional, tersedia di http://bappeda.jatimprov.go.id/2017/09/17/jatim-sumbang-50-persen-pendapatan-cukai-rokoknasional-148-triliun/ diunduh 25 Januari 2018

Biro Administrasi Perekonomian Sekretariat Daerah Provinsi Jawa Timur. 2016. Data Dinamis Perekonomia Jawa Timur Maret 2016

[BPS] Badan Pusat Statistik, 2015. Peranan Industri Dalam Perekonomian Jawa Timur 2015, BPS Jawa Timur

[BPS] Badan Pusat Statistik, 2016. Tabel I-O Provinsi Jawa Timur 2015, BPS Provinsi Jawa Timur, Surabaya

[BPS] Badan Pusat Statistik, 2016. Perkembangan Industri Besar dan Sedang Provinsi Jawa Timur Tahun 2011-2015, BPS Provinsi Jawa Timur, Surabaya

[BPS] Badan Pusat Statistik, 2017. Statistik Industri Manufaktur (Bahan Baku) Provinsi Jawa Timur, 2015, BPS Provinsi Jawa Timur, Surabaya

KADIN. 2016. Kadin Sebut Indonesia Alami Gejala Deindustrialisasi, tersedia di https://ekbis.sindonews.com/read/1140692/34/kadin-sebut-indonesia-alami-gejala-deindustrialisasi1474342240, diunduh pada 7 Desember 2017

KEMENPERIN. 2015. Kemenperin dorong pengolahan bahan baku lokal, tersedia di http://www.kemenperin.go.id/artikel/8394/Kemenperin-Dorong-Pengolahan-Bahan-Baku-Lokal, diunduh pada 5 Pebruari 2018.

Kuncoro, M, 2009. Ekonomika Indonesia Dinamika Lingkungan Bisnis di Tengah Krisis Global. UPP STIM YKPN

Rustiadi E, Sefulhakim S, Panuju DR, 2011. Perencanaan dan Pengembangan Wilayah. Jakarta (ID) : Crespent Press dan Yayasan Pustaka Obor Indonesia

Santoso EB, dan Suharjo ODM. 2014. Keterkaitan Sektor Ekonomi di Provinsi Jawa Timur, Jurnal Teknik Pomits Vol. 3, No. 2, (2014) ISSN: 2337-3539 (2301-9271 Print)

Suryani, Y. 2007. Input-Output Analysis To Agrigulture and Industri Sektors, Jurnal Ekonomi dan Bisnis, Volume 2 Nomor 2, Oktober 2007

Sinay, LJ. 2015. Sektor Pertanian merupakan Sektor Unggulan Terhadap Pembangunan Ekonomi Provinsi Maluku, Agriekonomika, ISSN 2301-9948, e ISSN 2407-6260, Volume 4, Nomor 2, Oktober 2015

Nazara, S. 2008. Sektor Industri Manufaktur dan Pembangunan Daerah (Manufacture sektor and regional development), Jurnal Riset Industri Vol 2 No 3, Desember 2008

Widyawati, RF. 2017. Analisis Keterkaitan Sektor Pertanian dan Pengaruhnya Terhadap Perekonomian Indonesia (Analisis Input Output), Jurnal Economia Volume 13 No 1, April 2017 